\title{
Karakteristik Parameter Oseanografi (Pasang-Surut, Arus, dan Gelombang) di Perairan Utara dan Selatan Pulau Bangka
}

\author{
Aditya Pamungkas* \\ Program Studi Ilmu Kelautan, Fakultas Pertanian, Perikanan, dan Biologi, Universitas Bangka Belitung \\ Jl. Kampus Terpadu UBB, Desa Balunijuk, Kecamatan Merawang, Kabupaten Bangka, Kepulauan Bangka Belitung \\ Email: aditya.pamungkas.ubb@gmail.com
}

\begin{abstract}
Abstrak
Perairan di Provinsi Kepulauan Bangka Belitung merupakan perairan yang terletak di Selat Karimata. Di sebelah utara Pulau Bangka, terdapat perairan Teluk Kelabat yang berhadapan dengan Laut Natuna.Sebaliknya, Selat Sadai terletak di sebelah selatan Pulau Bangka dan berhadapan langsung dengan Laut Jawa.Penelitian ini bertujuan untuk mengetaui karakteristik parameter oseanografi di perairan tersebut yang meliputi kondisi pasang-surut, arus, dan gelombang.Data yang dipergunakan untuk menganalisis ketiga parameter oseanografi tersebut diperoleh dari Badan Informasi Geospasial (BIG). Penelitian ini akan menfokuskan pada kondisi oseanografi pada Musim Timur (Juli 2017) dan Musim Barat (Januari 2018).Hasil analisis menunjukkan pasang-surut di kedua perairan tersebut bertipe diurnal dengan kategori makro-tidal di Teluk Kelabat dan meso-tidal di Selat Sadai dengan tunggang pasang surut masing-masing $3 \mathrm{~m}$ dan 2,5m.Selanjutnya, arah arus di perairan Teluk Kelabat dan Selat Sadai mempunyai pola yang mengikuti arah angin di tiap musimnya dan kecepatannya cenderung lebih tinggi di musim barat.Kecepatan arus berkisar antara $0.2-0.3 \mathrm{~m} /$ det. Untuk karakteristik gelombang, tinggi gelombang signifikan di perairan utara Pulau Bangka (Teluk Kelabat) cenderung lebih besar yaitu berkisar antara 0.1-0.5 m. Sedangkanperairan selatan Pulau Bangka (Selat Sadai) tinggi gelombang berkisar antara 0.1-0.3 m. Tinggi gelombang cenderung lebih besar ketika Musim Barat dibandingkan ketika Musim Timur.
\end{abstract}

Kata Kunci: Parameter oseanografi, Perairan Bangka, Teluk Kelabat, Selat Sadai

\section{Abstract}

\section{Characteristics of Oceanographic Parameters (Tidal, Flow, and Waves) in North and South of Bangka Island}

Bangka Belitung seas is located in the Karimata Strait. In the North of Bangka Island, there are Kelabat Bay that the Natuna Sea was confronted with. Instead, Sadai Strait is located at south Bangka Island and dealing directly with the Java Sea. This study will compare the oceanographic characteristics in both region which include tidal conditions, currents, and waves. The data are used to analyze the third oceanographic parameters obtained from the Badan Informasi Geospasial (BIG). In this research will be focusing on the oceanographic conditions in the east monsoon (July 2017) and west monsoon (January 2018). The results of this research shows the tides in both the waters of diurnal with the category macro-tidal at the Kelabat Bay and meso-tidal at Strait Sadai with the tidal range are $3 \mathrm{~m}$ and 2,5m. Furthermore, the direction of the currents in the waters of Kelabat Bay and Strait Sadai will follow the wind direction in every season and tends to be higher at west monsoon with the current veolcity around $0.2-0.3 \mathrm{~m} / \mathrm{s}$. For the wave characteristics, significant wave height in north seas of the Bangka Island (Kelabat Bay) tend to be larger, around 0.1-0.5m when compared with south seas of Bangka Island (Sadai Strait) around 0.1-0.3m and tend to be higher when west monsoon than east monsoon.

Keywords : Oceanography parameters, Bangka Sea, Kelabat Bay, Sadai Strait

\begin{tabular}{lll}
\hline$*$ Corresponding author & http://ejournal.undip.ac.id/index.php/buloma & Diterima/Received : 14-01-2018 \\
buloma.undip@gmail.com & & Disetujui/Accepted : 04-03-2018
\end{tabular}




\section{PENDAHULUAN}

Perairan Kepulauan Indonesia terletak di antara dua benua yakni Benua Asia dan Australia serta diapit oleh dua samudera yakni Samudera Hindia dan Pasifik.Kondisi inilah yang menyebabkan perairan Indonesia sangatlah dipengaruhi oleh monsoon yang bergerak dari Benua Asia ke Australia dan sebaliknya (Ningsih et al., 2000). Pengaruh monsoon ini tentunya akan mempengaruhi karateristik oseanografi perairan di Indonesia termasuk perairan Bangka Belitung.

Provinsi Kepulauan Bangka Belitung yang secara geografis terletak pada koordinat $104^{\circ} 50^{\prime}$ $108^{\circ} 18^{\prime}$ BT dan $1^{\circ} 20^{\prime}-3^{\circ} 15^{\prime}$ LS dikenal memiliki potensi di bidang kelautannya, baik dari segi pariwisata hingga potensi perikanannya. Daerah yang berpotensi ini antara lain Teluk Kelabat dan Selat Sadai. Teluk Kelabat sendiri terletak di pesisir utara Pulau Bangka dan menghadap langsung ke Laut Natuna sedangkan Selat Sadai terletak di pesisir selatan Pulau Bangka dan berhadapan langsung dengan Laut Jawa. Kondisi geografis perairan yang berbeda menyebabkan perbedaan karakteristik parameter oseanografi di wilayah tersebut. Penelitian ini bertujuan untuk mengetahui karakteristik parameter oseanografi pesisir utara dan selatan Pulau Bangka. Karakteristik oseanografi tersebut meliputi kondisi pasang-surut, arus, dan gelombang.

\section{MATERI DAN METODE}

Penelitian ini difokuskan kepada dua daerah kajian yaituperairan utara Pulau Bangka yang diwakili oleh perairan Teluk Kelabat dan perairan selatan Pulau Bangka yang diwakili oleh perairan Selat Sadai (Gambar 1). Secara geografis, perairan Teluk Kelabat berada di sekitar koordinat $105,25-106.2^{\circ} \mathrm{BT}$ dan $1.22-1.85^{\circ} \mathrm{LS}$ sedangkan perairan Selat Sadai terletak pada $106.5-107^{\circ} \mathrm{BT}$ dan $2.63-3.24^{\circ}$ LS.Perairan Teluk Kelabat yang berada di utara Pulau Bangka langsung berhadapan dengan laut Natuna mempunyai perbedaan kondisi geografis dengan perairan Selat Sadai yang merupakan selat sempit di Selatan Pulau Bangka.Karakteristik oseanografi dalam penelitian ini meliputi pasang-surut, arus, dan gelombang laut.Data pasang-surut, arus, dan gelombang laut yang dipergunakan dalam penelitian ini adalah data yang berasal dari Badan Informasi Geospasial (BIG) yang dapat diakses melalui http://tides.big.go.id.

BIG menyediakan data-data prediksi yang cukup lengkap antara lain data pasang-surut, arus, dan gelombang yang merupakan reanalysis data lapangan dan data hasil model sehingga tingkat keakuratan datanya cukup baik. Data ini mempunyai resolusi sebesar $5 \mathrm{~km}$ sehingga dapat dipergunakan untuk melihat kondisi di suatu perairan. Untuk karakteristik arus laut dan gelombang, data yang dipergunakan adalah data pada tanggal 1-31 Juli 2017 yang mewakili musim timur dan 1-31 Januari 2018 yang mewakili musim barat. Sedangkan untuk kondisi pasang-surut hanya akanmenggunakan data pada tanggal 1-31 Januari 2018 karena pasang-surut tidak terlalu dipengaruhi oleh musim.

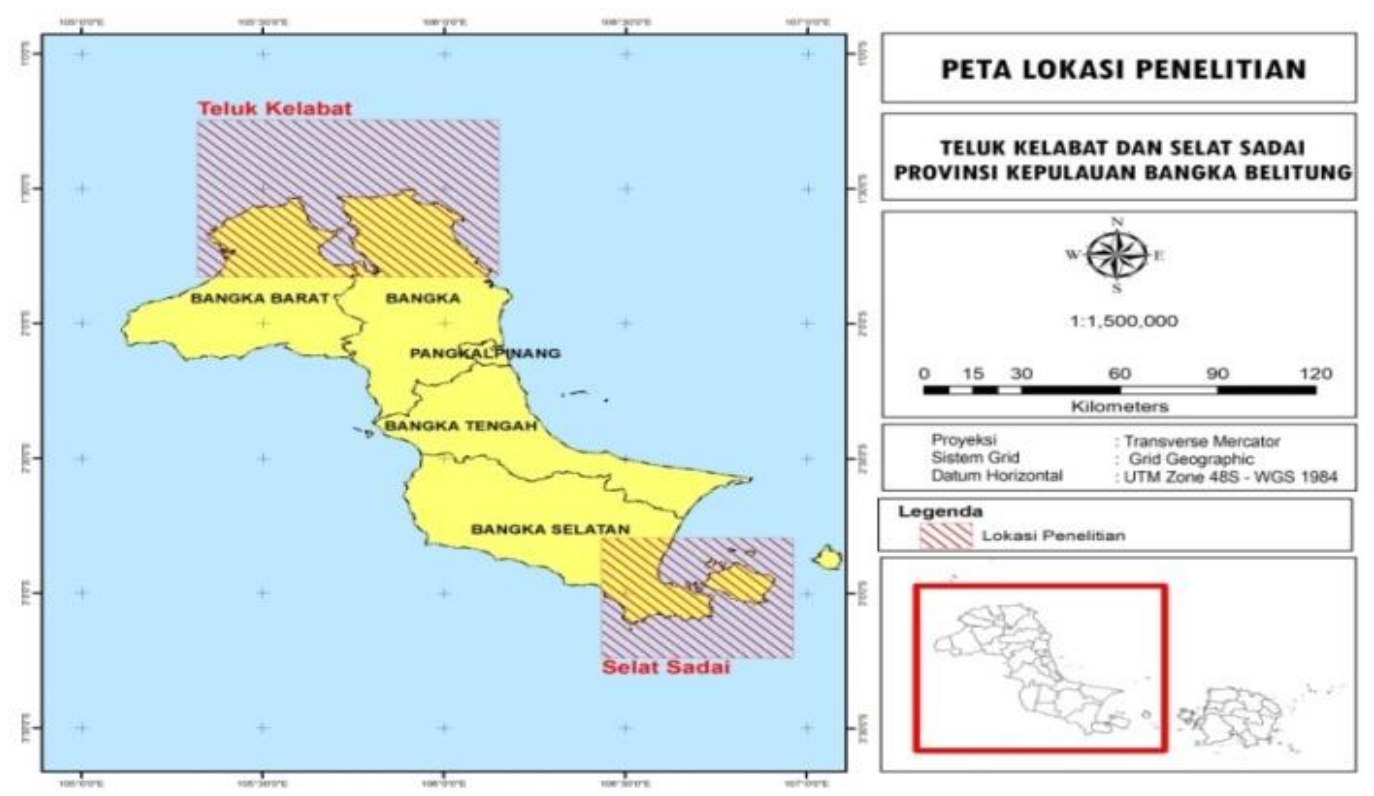

Gambar 1. Lokasi kajian dalam penelitian ini 

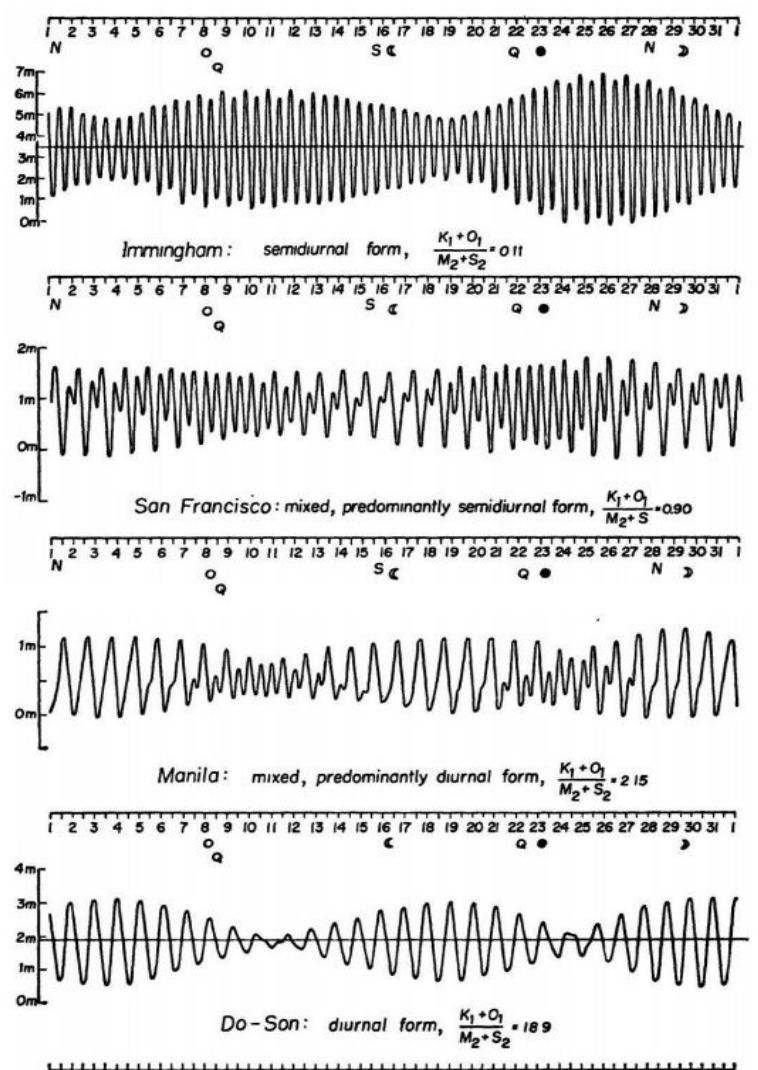

FIG. 35. Tidal curves during March, 1936 (from German Tide Tables for the year 1940, Vol. II, Berlin, 1939).

, ), $\mathbb{Q}$ : phases of the moon. $\mathrm{N}$ : maximum northern declination of the moon; $S$ : maximum southern declination of the moon; Q: moon's transit through equator.

Gambar 2. Kurva standar tipe pasang-surut (Magori, 2009)

Analisis arus akan dilakukan melalui pola arus permukaan yang meliputi arah serta kecepatan arus permukaan. Sementara itu, tinggi dan periode signifikan gelombang akan digunakan untuk menganalisis karakteristik gelombang pada penelitian ini. Untuk analisis pasang-surut, pada penelitian ini akan mengkaji tipe pasang surut berdasarkan Magori (2009) serta kategori pasangsurut berdasarkan tunggang pasut saat pasang purnama (spring tidal range) menurut Magori (2009). Magori (2009) menjelaskan bahwa range pasang-surut dapat dikategorikan Mikro-tidal (kisaran $0.3-1 \mathrm{~m}$ ), Meso-tidal (kisaran $1-2 \mathrm{~m}$ ), dan Makro-tidal (kisaran > 3m).

\section{HASIL DAN PEMBAHASAN \\ Pasang-surut}

Dari data pasang surut yang diperoleh dari BIG, elevasi pasang surut di perairan Teluk Kelabat dan Selat Sadai disajikan pada Gambar 3 dan analisisnya berdasarkan Magori (2009) disajikan pada Tabel 1. Pasang-surut pada daerah utara Pulau Bangka yang diwakili oleh perairan Teluk Kelabat dan daerah selatan Pulau Bangka yang diwakili oleh perairan Selat Sadai (Gambar
3) sama - sama memiliki tipe pasang surut diurnal. Pasang surut tipe ini dalam sehari akan terjadi satu kali pasang dan satu kali surut. Hal ini dapat terlihat jelas pada tanggal 3-6 Januari 2018 terjadi sekali pasang dan sekali surut dimana elevasinya sekitar $1.5 \mathrm{~m}$ di perairan Teluk Kelabat dan sekitar $1.25 \mathrm{~m}$ di perairan Selat Sadai.

Elevasi pasang-surut di perairan Teluk kelabat berkisar antara $0.5-1.5$ meter.Saat terjadi pasang purnama (spring tide) tunggang pasut pada perairan ini dapat mencapai > 3 meter seperti yang terlihat pada tanggal 4 Januari 2018.Oleh karena itu, berdasarkan klasifikasi range pasangsurut dari Magori (2009), pasang-surut di perairan Teluk Kelabat merupakan kelompok makro-tidal. Sedangkan untuk perairan Selat Sadai walaupun memiliki tipe pasang surut yang sama dengan perairan Teluk Kelabat, nilai elevasi pasang surut di Selat Sadai cenderung lebih kecil dimana berkisar antara $0.4-1.25$ meter. Sehingga dengan nilai elevasi tersebut dan berdasarkan klasifikasi dari Magori (2009), pasang-surut di perairan Selat Sadai memiliki tunggang pasut ketika pasang purnama sebesar 2.5 meter dan dapat dikelompokan kedalam kategori meso-tidal. 
Berdasarkan penelitian ini menunjukkan bahwa pasang-surut di wilayah utara dan selatan Pulau Bangka mempunyai tipe pasang surut yang sama yaitu tipe diurnal sebagaimana ditunjukan tipe pasang surut di Teluk Kelabat dan Selat Sadai. Tipe diurnal di kedua perairan ini konsisten dengan tipe pasang-surut yang diperoleh pada penelitian Ray (2005).Perlu diketahui bahwa Ray (2005) meneliti pasang-surut berdasarkan analisa data muka air laut selama 10 tahun yang diperoleh dari satelit altimetri Topex/Poseidon.

Apabila kita uraikan pasang-surut di wilayah tersebut kita dapat memperoleh komponen-komponen penyusun pasang surut, salah satunya dengan menggunakan metode Least Square(Yusuf, 2013).Komponen-komponen utama pasang-surut diperairan tersebut disajikan dalam tabel 2.Melalui nilai komponen-komponen pasang-surut tersebut, kita juga dapat mengetahui

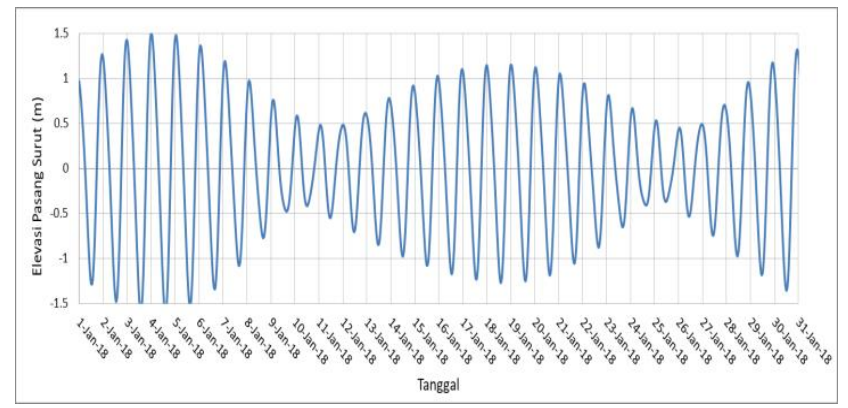

A: Teluk Kelabat (1 - 31 Januari 2018) tipe pasang surut melalui bilangan Formzahlnya.Bilangan Formzahl merupakan pembagian antara penjumlahan dua komponen utama diurnal (K1 dan O1) dengan penjumlah komponen utama semi-diurnal (M2 dan S2) (Duxburyet al., 2002).Nilai Formzahl yang diperoleh pada perairan adalah sebesar 10.67 yang menandakan tipe pasang surut perairan ini adalah diurnal.Selanjutnya, melalui komponenkomponen pasang surut ini juga dapat diketahui level-level muka air seperti MSL, HHWL, LLWL, dan sebagainya (Gambar 4.)

Arus

Perairan Indonesia sangatlah dipengaruhi oleh angin monsoon (Hadi dan Radjawane, 2011). Angin monsoon ini terbagi menjadi dua fase yaitu musim timur yang terjadi pada bulan Juni-JuliAgustus (JJA) dan musim barat yang terjadi pada

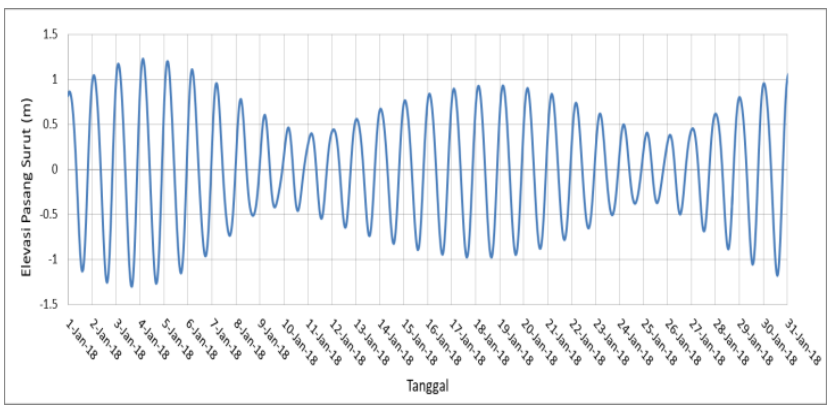

B: Selat Sadai (1 - 31 Januari 2018)

Gambar 3. Pasang-surut di perairan Teluk Kelabat (kiri) dan Selat Sadai (kanan) pada bulan Januari 2018

Tabel 1. Karakter pasang-surut di perairan Teluk Kelabat dan Selat Sadai

\begin{tabular}{lcc}
\hline & Teluk Kelabat & Selat Sadai \\
\hline Tipe pasang-surut & Diurnal $(1$ pasang -1 surut $)$ & Diurnal $(1$ pasang -1 surut $)$ \\
Elevasi pasang-surut & $0,5-1,5$ meter & $0,4-1,25$ meter \\
Spring tidal range $*$ & 3 meter (makro-tidal) & 2,5 meter (mikro-tidal) \\
\hline
\end{tabular}

Keterangan : $*$ = Kategori pasang-surut berdasarkan Magori (2009)

Tabel 2.Komponen - komponen utama pasang surut

\begin{tabular}{cccc}
\hline Komponen & Frekuensi & Amplitudo & Fase \\
\hline M2 & 0.080 & 0.077 & 344.5 \\
S2 & 0.083 & 0.028 & 160.93 \\
N2 & 0.079 & 0.014 & 262.67 \\
K2 & 0.084 & 0.026 & 225.18 \\
K1 & 0.042 & 0.679 & 32.44 \\
O1 & 0.039 & 0.44 & 336.67 \\
P1 & 0.042 & 0.225 & 39.51 \\
\hline
\end{tabular}




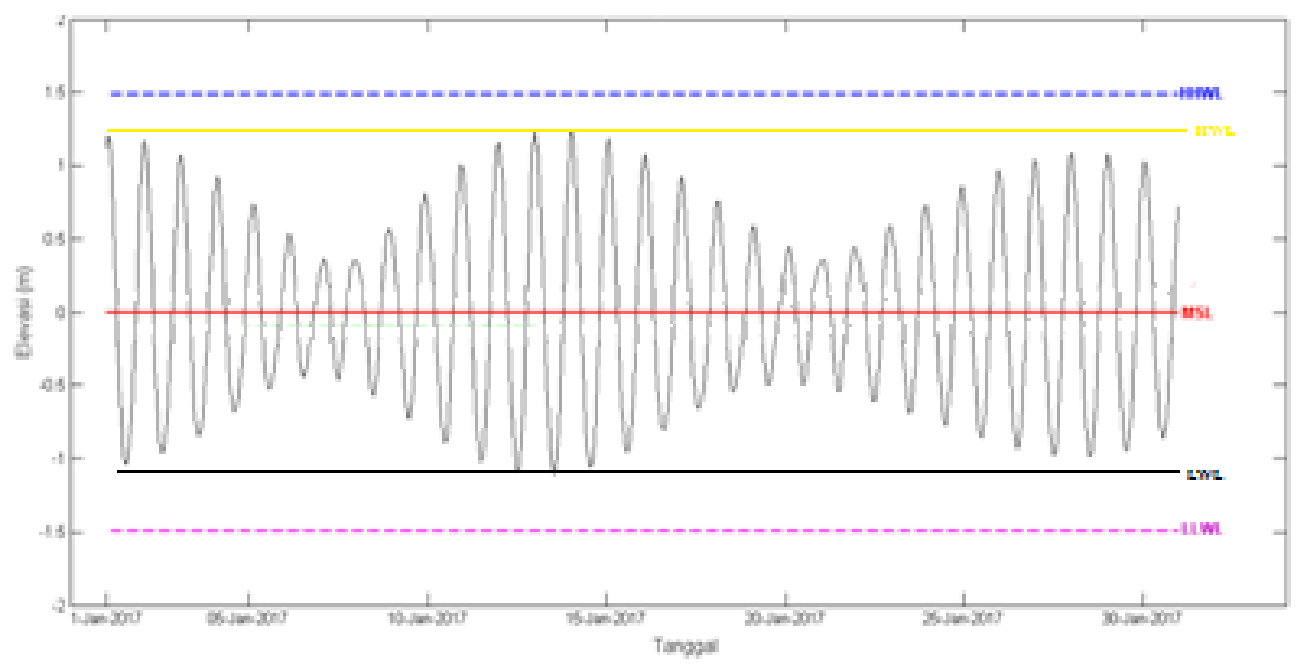

Gambar 4.Kondisi MSL, MHWL, HHWL, MLWL, dan LLWL

bulan Desember-Januari-Februari (DJF) (Weiet al., 2015).Ketika musim timur, angin bergerak dari Benua Asia menuju Benua Australia. Berkebalikan dengan musim timur, pada musim barat angin akan bergerak dari Benua Australia menuju Benua Asia (Purba, 2014). Pengaruh angin monsoon inipun juga akan mempengaruhi perairan Bangka terutama karena letaknya yang terletak antara Laut Natuna dan Laut Jawa yang merupakan daerah aliran angin monsoon (Setyawan dan Pamungkas, 2017).

Pola arus permukaan di perairan Teluk Kelabat (Gambar 4) menunjukan arah arus yang sangat berbeda antara musim timur $(1-31$ Juli 2017) terhadap arah arus pada musim barat (1 31 Januari 2018). Faktor utama yang membedakan pola arah arus tersebut adalah angin monsoon.Pada musim timur, arus permukaan di Teluk Kelabat bergerak dominan dari arah selatan menuju utara. Arus ini akan menyusuri pesisir timur laut Pulau Bangka kemudian bergerak ke arah barat menuju Selat Bangka dengan kecepatan yang berkurang drastis. Kecepatan arus di daerah utara Pulau Bangka ini berkisar antara 0,01-0.19 $\mathrm{m} / \mathrm{dt}$ dimana daerah timur memiliki kecepatan arus yang tinggi dan daerah utara-barat memiliki arus yang relatif kecil. Pola arah arus ini akan berbalik pada musim barat (1 - 31 Januari 2018) ketika angin bergerak dari Laut Natuna menuju Laut Jawa. Arah arus pada musim barat bergerak dominan ke arah timur dan selatan menyusuri pesisir utara Pulau Bangka. Untuk kecepatan arus, musim barat memiliki nilai kecepatan arus berkisar antara $0,01-0.28 \mathrm{~m} / \mathrm{dt}$. Sehingga dapat disimpulkan bahwa arah arus di perairan Teluk Kelabat konsisten dengan arah angin monsoon di tiap musimnya dan kecepatan arus di musim barat cenderung lebih besar apabila dibandingkan dengan musim timurnya.

Untuk perairan selatan Pulau Bangka yang diwakili oleh perairan Selat Sadai, pola arus permukaan di perairan ini (Gambar 5) juga menunjukan arah arus yang sangat berbeda antara musim timur ( 1 - 31 Juli 2017) terhadap arah arus pada musim barat (1 - 31 Januari 2018). Pada musim timur, arus permukaan di Selat Sadai bergerak dominan dari arah selatan menuju utara. Arus ini akan menyusuri pesisir selatan Pulau Bangka ke arah timur kemudian bergerak ke arah utara menuju Laut Natuna mengikuti pola angin pada musim timur.

Kecepatan arus di daerah Selat Sadai ini berkisar antara $0,01-0.185 \mathrm{~m} / \mathrm{dt}$ dimana nilai ini relatif sama dengan kecepatan arus di daerah Teluk Kelabat. Pola arah arus ini akan berbalik pada musim barat (1 - 31 Januari 2018) ketika angin bergerak ke Laut Jawa. Arah arus pada musim barat bergerak dominan ke arah selatan menyusuri pesisir timur Pulau Bangka dan kemudian berbelok ke arah barat. Untuk kecepatan, arus di musim barat memiliki berkisar antara $0,01-0.43 \mathrm{~m} / \mathrm{dt}$ dimana merupakan kecepatan arus tertinggi apabila dibandingkan dengan kecepatan arus Selat Sadai ketika musim timur maupun kecepatan di Teluk Kelabat. Berdasarkan penjelas diatas dapat disimpulkan bahwa arah arus di perairan Selat Sadai konsistendengan arah angin monsoon di tiap musimnya dan memiliki kecepatan arus yang lebih tinggi ketika musim barat sama halnya seperti yang terjadi di perairan utara Pulau Bangka di perairan Teluk Kelabat. 


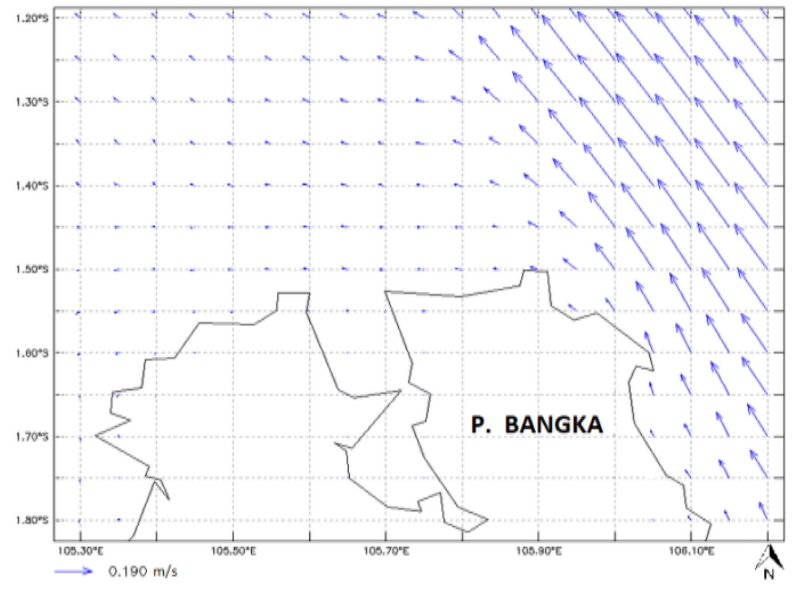

A: Musim timur (1-31 Juli 2017)

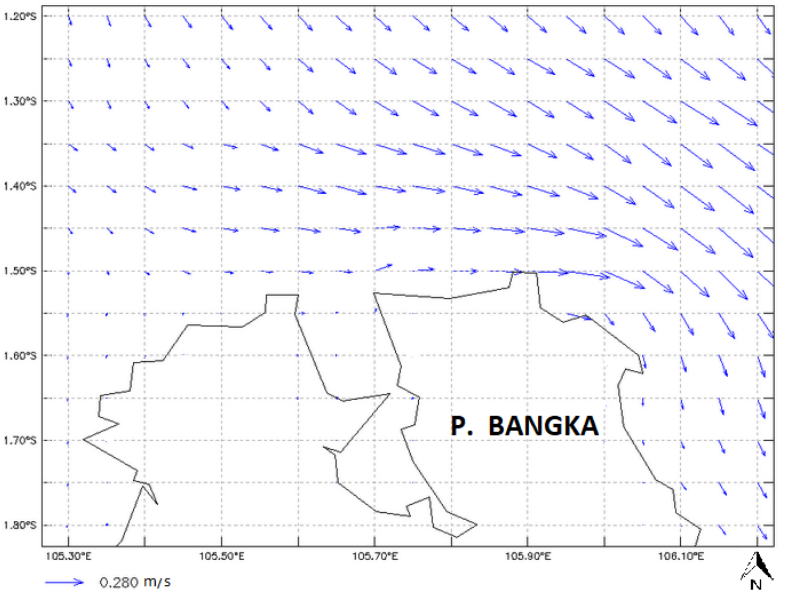

B: Musim barat (1-31 Januari 2018)

Gambar 5. Pola arus di perairan Teluk Kelabat pada musim timur dan musim barat

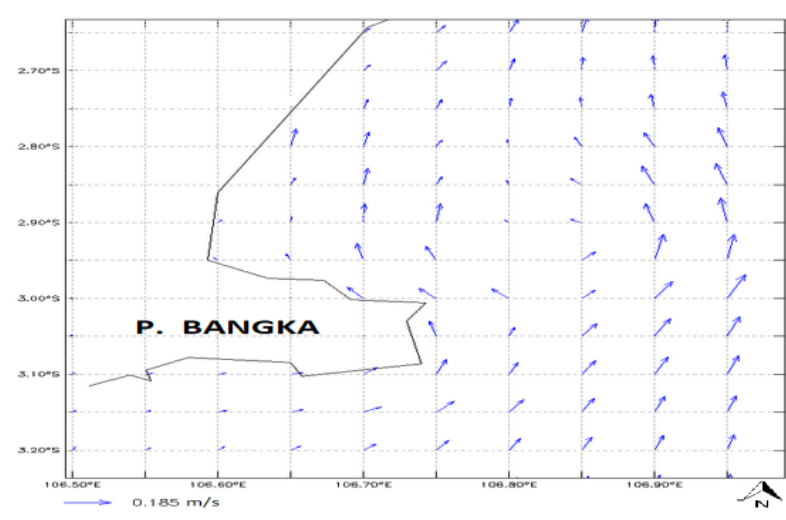

A: Musim timur (1-31 Juli 2017)

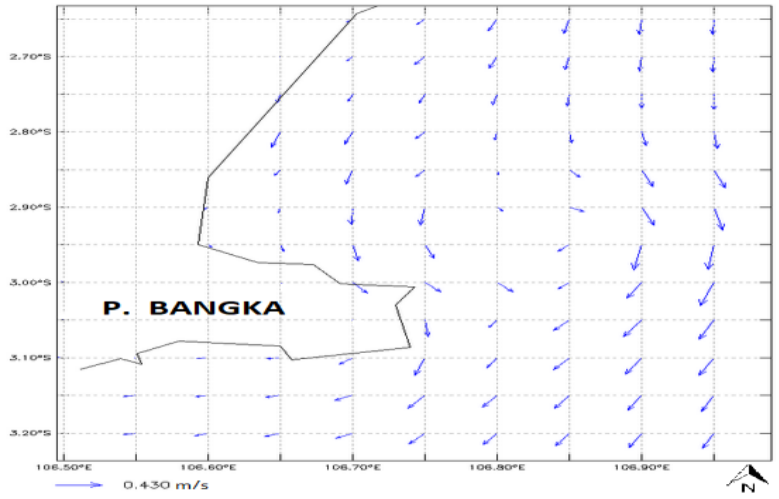

B: Musim barat (1-31 Januari 2018)

Gambar 6. Pola arus di perairan Selat Sadai pada musim timur dan musim barat

\section{Gelombang}

Selain karakteristik arus, angin monsoon juga akan mempengaruhi karakteristik gelombang di suatu perairan. Hal ini dikarenakan gelombang terbentuk akibat adanya gaya gesek angin di permukaan angin dan terjadi transfer energi (Kumaret al., 2010). Sehingga untuk mendeskripsikan karakteristik suatu perairan diperlukan analisa gelombang tersebut antara musim barat dan musim timur.Salah satu parameter yang penting untuk diperhatikan adalah tinggi gelombang signifikan $\left(\mathrm{H}_{\mathrm{s}}\right)$ di kedua musim tersebut (Jiang dan Chen, 2013).Grafik tinggi gelombang signifikan pada perairan Teluk Kelabat disajikan pada Gambar 6 dan perairan Selat Sadai pada Gambar 7.

Pada daerah perairan utara Pulau Bangka yang diwakili oleh daerah Teluk Kelat, tinggi gelombang signifikan berkisar antara 0,02-0,21 meter pada musim timur (Gambar 6 atas) dan meningkat drastis pada musim barat yang berkisar antara 0,01-0,5 meter. Ketika musim barat (1-31 Januari 2018), angin berhembus dari Benua Asia menuju Benua Australia dan melewati perairan Indonesia. Pada masa - masa ini gelombang akan cukup besar dikarenakan gelombang yang terbentuk di Laut Natuna akan menjalar hingga ke pesisir utara Pulau Bangka (Teluk Kelabat). Sebaliknya ketika musim timur, angin dan gelombang akan menjalar dari perairan Jawa menuju Laut Natuna. Sehingga di pesisir utara Pulau Bangka yang terlindung, tinggi gelombang signifikan akan cenderung lebih kecil.

Sama seperti perairan Teluk Kelabat, perairan Selat Sadai juga memiliki tinggi gelombang yang lebih tinggi pada musim timur. Pada daerah perairan Selat Sadai yang merupakan daerah selatan Pulau Bangka, tinggi gelombang signifikan berkisar antara 0,01 - 0,19 meter pada musim timur (Gambar 7 atas) dan meningkat pada 


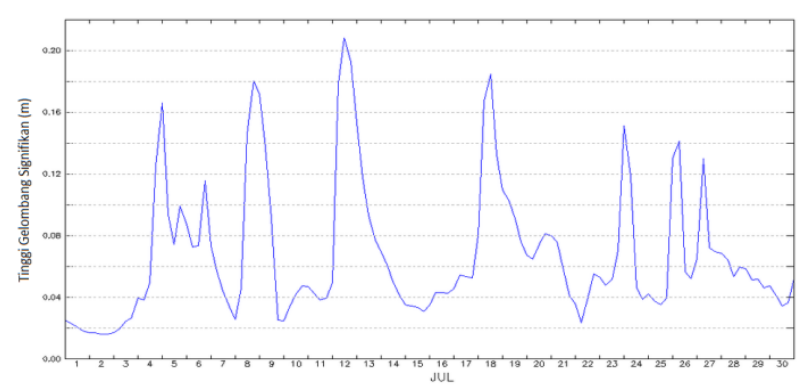

A: Musim timur (1-31 Juli 2017)

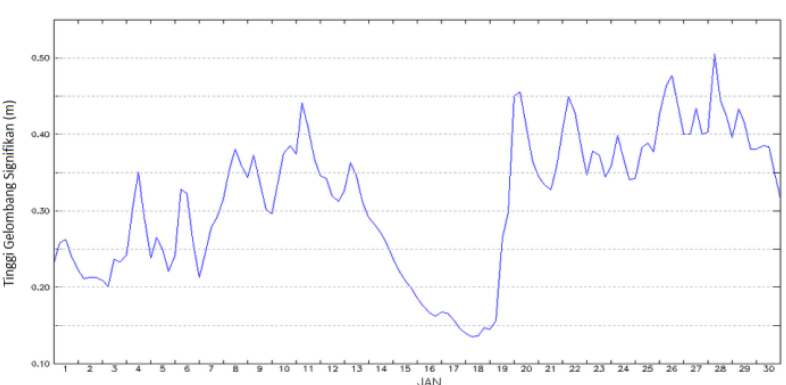

B: Musim barat (1-31 Januari 2018)

Gambar 7. Tinggi gelombang signifikan di perairan Teluk Kelabat pada musim timur dan musim barat

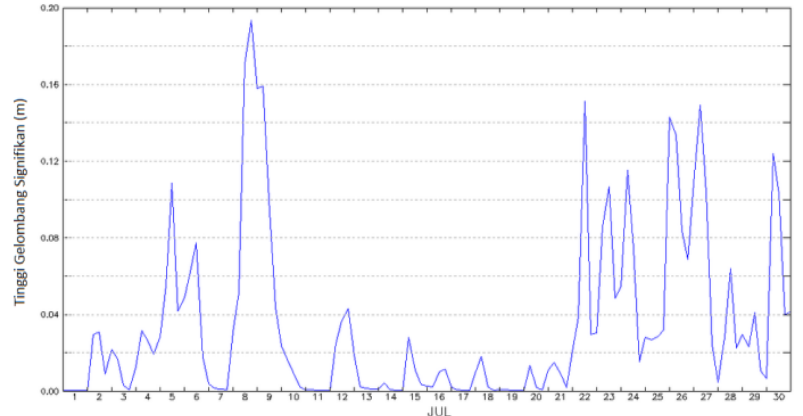

A: Musim timur (1-31 Juli 2017)

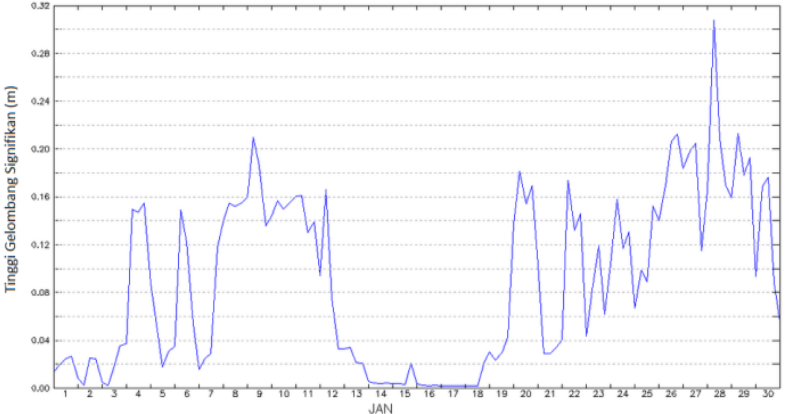

B: Musim barat (1-31 Januari 2018)

Gambar 8. Tinggi gelombang signifikan di perairan Selat Sadai pada musim timur dan musim barat

musim barat yang berkisar antara $0,01-0,31$ meter. Ketika musim barat (1-31 Januari 2018).Karakteristik tinggi gelombang signifikan pada perairan di utara dan selatan Pulau Bangka relatif serupa dimana terjadi peningkatan gelombang pada musim barat.Tinggi gelombang signifikan pada daerah Selat Sadai cenderung lebih kecil apabila dibandingkan dengan daerah Teluk Kelabat.Hal ini dikarenakan daerah Selat Sadai merupakan daerah selat sempit dan dangkal serta terlindungi oleh beberapa pulau disekitarnya, sedangkan daerah Teluk Kelabat merupakan daerah perairan terbuka dan langsung berhadapan dengan Laut Natuna. Sehingga gelombang akan lebih mudah menjalar ke perairan Teluk Kelabat sedangkan gelombang akan mudah terdisipasi (berkurangnya energi gelombang) di perairan Selat Sadai.

\section{KESIMPULAN}

Perairan di Teluk Bangka dapat dibagi menjadi dua bagian yaitu perairan Teluk Kelabat yang berada di utara dan berhadapan Laut Natuna serta perairan Selat Sadai yang berada di selatan dan berhadapan dengan Laut Jawa.Dalam penelitian ini, dikaji kondisi oseanografi yang meliputi arus, pasang-surut, dan gelombang di kedua perairan ini dengan mempergunakan data yang diperoleh dari Badan Informasi Geospasial.Hasil analisis pada penelitian ini menunjukan di kedua perairan tersebut memiliki karakteristik oseanografi yang sangat terpengaruh oleh angin monsoon (musiman) terutama gelombang dan arusnya. Arah arus di perairan Teluk Kelabat dan Selat Sadai akan mengikuti arah angin di tiap musimnya dengan kecepatan arus berkisar antara $0.2-0.3 \mathrm{~m} / \mathrm{det}$ dan kecepatannya cenderung lebih tinggi di musim barat. Untuk karakteristik gelombang, tinggi gelombang signifikan di perairan utara Pulau Bangka cenderung lebih besar yang berkisar antara 0.1-0.5 $\mathrm{m}$ apabila dibandingkan dengan Selat Sadai yang berkisar $0.1-0.3 \mathrm{~m}$ serta cenderung lebih besar ketika musim barat dibandingkan ketika musim timur.Sementara itu, pasang-surut di kedua perairan tersebut bertipe diurnal dengan kategori makro-tidal di Teluk Kelabat dan meso-tidal di Selat Sadai dengan tunggang pasang surut masing-masing $3 \mathrm{~m}$ dan $2,5 \mathrm{~m}$.

DAFTAR PUSTAKA

Duxbury, A.B., Duxbury, A.C., \& Sverdrup, K.A. 2002.Fundamental of Oceanography $4^{\text {th }}$ Edition.McGraw-Hill. ISBN 0-08242790-6 
Hadi, S., \& Radjawane, I. 2011.Arus laut. Institut Teknologi Bandung Press, Bandung.

Jiang, H., \& Chen, G. 2013. A global view on the swell and wind sea climate by the Jason-1 mission: a revisit. Journal of Atmospheric and Oceanic Technology, 30(8):1833-1841. DOI: 10.1175/JTECH-D-12-00180-1

Kumar, V.S., Philip, C.S., \& Nair, T.B. 2010. Waves in shallow water off west coast of India during the onset of summer monsoon. Ann. Geophys. 28:817-824.

Magori, C. 2009. Tidal Analysis and Prediction in the Western Indian Ocean.Regional Report.Western Indian Ocean Marine Science Associationand Intergovernmental Oceanographic Commission.44 pp.

Ningsih, N.S., Yamashita, T., \& Aouf, L. 2000. Three-dimensional simulation of water circulation in the Java Sea: influence of wind waves on surface and bottom stresses. In Natural Hazards pp.145-171.

Ray, R.D., Egbert, G.D., \& Erofeeva, S.Y. 2005.A brief overview of tides in the Indonesian Seas.Oceanography, 18(4):74-79.
Purba, N.P. 2014. Variabilitas Angin dan Gelombang Laut Sebagai Energi Terbarukan di Pantai Selatan Jawa Barat. Jurnal Akuatika, 5(1).

Setyawan, W.B., \& Pamungkas, A. 2017 Perbandingan Karakteristik Oseanografi Pesisir Utara Dan Selatan Pulau Jawa: Pasang-surut, Arus, dan Gelombang.Prosiding Seminar Nasional Kelautan dan Perikanan III 2017. Universitas Trunojoyo Madura.

Wei, Z.X., Fang, G.H., Susanto, R.D., Adi, T.R., Fan, B., Setiawan, A., \&Gao, X.M. 2015. Tidal elevation, current and energy flux in the area between the South China Sea and Java Sea. Ocean Sci. Discuss. 12(6):517531. DOI : 10.5194/os-12-517-2016

Yusuf, M. \& Yanagi, T. 2013.Numerical Modelling of Tidal Dynamics in the Java Sea. Coastal Marine Science. 36(1):1-12 